\title{
Does attending a large science event enthuse young people about science careers?
}

\section{Sam Illingworth, Emma Lewis and Carl Percival}

\begin{abstract}
A survey was conducted during the University of Manchester's 2014 'Science Extravaganza', which saw the participation of over 900 Key Stage 3 (ages 11-14) students in a range of interactive demonstrations, all run by active University researchers. The findings of this study suggest that a new approach is necessary in order to use these large science events to actively engage with school students about the career opportunities afforded by science subjects. Recommendations for such an approach are suggested, including the better briefing of researchers, and the invitation of scientists from outside academia to attend and interact with the school students.
\end{abstract}

Keywords

Perceptions of science and technology; Public engagement with science and technology

The Wellcome Trust Monitor was originally conceived in 2009 as a way to track over time the public's interest in, attitudes towards, and experience and knowledge of science. Of the 306 young people, aged between 14 and 18 years, interviewed for the 2013 report [Clemence et al., 2013], 82\% stated that they found their school science lessons to be interesting. However, whilst $82 \%$ of them also considered science to be a good area of employment to go into (citing good pay, interesting work, and the ability to make interesting discoveries as the main reasons for thinking so), $64 \%$ of them reported that they knew little or nothing about what such scientific (63\%) or STEM (Science, Technology, Engineering and Maths) careers (55\%) would actually entail.

The prevailing view of the STEM career progression is that young children initially have a high level of interest in science and mathematics, but that, as they move through the educational system, interest is lost at every stage [Sadler et al., 2012]. Whilst the results of the Wellcome Trust's survey would seem to indicate that there is still enthusiasm in science subjects at the secondary school level, they also suggest that scientific careers may not be pursued by young people because of a lack of information, rather than because of a lack of desire.

With most of the young people interviewed for the report saying that they received careers advice from either their family $(67 \%)$ or teachers $(49 \%)$, there is the possibility that their future career paths are being biased towards areas in which these sources are able to provided guided support. In addition to this, only $10 \%$ of 
young people thought that careers advice from someone working in the STEM field was amongst the most useful that they could receive. Is this because they do not wish to pursue a STEM-related career, or because they do not identify with scientists as people like them, but rather see them as stereotypical caricatures [Buldu, 2006]? Is there maybe something that could be done outside of a classroom environment, to further educate students about what a science-related career entails and how to pursue one?

As noted by Baram-Tsabari and Yarden [2005, pp. 823], "school science does not hold a monopoly on the dissemination of scientific knowledge." There are many different environments outside of school in which students can continue to learn about science in a more informal setting, including museums, science centres and zoos [see e.g. Ramey-Gassert, 1997]. Informal learning can be considered to be that which occurs outside of the traditional, formal schooling realm, although as noted by Dierking et al. [2003], informal science education is not just defined by learning that takes place outside of the classroom, but as something that is self-motivated and guided by the learner's needs and interests.

Large science events often take place in these informal settings (i.e. not in schools), and include science festivals [see e.g. Jensen and Buckley, 2014], science fairs [see e.g. Martín-Sempere, Garzón-García and Rey-Rocha, 2008], and public lectures [see e.g. Gregory and Miller, 2000], many of which have specific events or activities for school children. For example, the Royal Institution Christmas Lectures in the UK have been running since 1825, and are aimed at a mainly teenage audience [Gjersoe and Hood, 2013], taking place at the Royal Institution in London each year.

Informal science activities have been shown to foster a strong commitment to science and science learning [Tamir, 1991], with informal learning also being shown to have a strong impact on future academic career choices amongst undergraduate students [see e.g. Salmi, 2003]. Similarly, previous studies have shown that workshops involving informal settings, and aimed at learners aged between 6 and 11 can instil very positive changes to the learners' views of science and scientists [see e.g. Muller et al., 2013]. It is the purpose of this work to determine if a large-scale science event, set in an informal setting and aimed at UK students in years 7,8 and 9 (ages 11-14) can have a similar effect, by enthusing young people in regards to science-related careers.

National Science and Engineering Week (NSEW) is a 10-day programme of STEM events and activities across the UK, aimed at people of all ages [see Bultitude, McDonald and Custead, 2011, and references therein]. Anyone can organise events and submit to the British Science Association (BSA) website for promotion, leading to an eclectic and varied programme of events [see e.g. Redfern, Burdass and Verran, 2013]. From 2015 onwards, NSEW will be known as 'British Science Week'.

Annually since 2010, the University of Manchester has organised various events for different age groups as part of NSEW. These include guest lectures, visit days and, since 2011, a 'Science Extravaganza' aimed at students in Key Stage 3 (ages 11-14), the format of which consists of: a science fair; a workshop, led by PhD STEM students; and a lecture from a STEM academic. 
The science fair takes place in a large hall, and consists of a number of different stations that are staffed by University of Manchester research staff and students, which are then visited by the school students. The students are encouraged to engage with a large variety of interactive science experiments and demonstrations. In 2014, the activities that were available at these stations covered a wide range of topics and science disciplines, all of which had an interactive element with which to engage the school students. These activities were also designed to teach the school students about an aspect of science, and to provide them with the opportunity to interact with the University's researchers. In total there were over 30 activities, which included making a cloud in a bottle, measuring the speed of aquatic \& semi-aquatic animals, and investigating Young's modulus using biscuits.

The 2014 Science Extravaganza event, which saw the participation of over 900 students from the Greater Manchester area, forms the basis of the analysis that is carried out in this study, which aims to assess what effect, if any, the event had on the students involved, in terms of both their perception of science researchers and of science as a potential career aspiration. Prior to the event it was expected that the activities on offer would enthuse the students about science, and that the opportunity to interact with science researchers and university students would encourage them to pursue an active interest in a science career, and also to view these scientists as a useful resource for career information.

Evaluation of the Science Extravaganza was carried out to highlight areas for inclusion and improvement for future years, and to evaluate the impact of the event on the attendees. This evaluation took the form of a series of questionnaires that were distributed during the Science Extravaganza to students and teachers, which asked them the extent to which they agreed with a number of prescribed statements; there was also the opportunity to respond in detail to some more open-ended questions. This study was carried out according to the British Educational Research Association's (BERA) ethical guidelines for educational research. The teacher's verbal consent to the evaluation, on behalf of the minors, was recorded, and no identification information for the minors was collected as part of this study. The questionnaires that were distributed to the students and the teachers are shown in appendix 1 and appendix 2 , respectively.

In total, 821 and approximately 80 questionnaires were distributed to students and teachers, respectively. Of these, the students returned 609 questionnaires, and the teachers returned 61. The questionnaires were filled in and collected at the event itself, and whilst the students and teachers were encouraged to fill them in, it was not a prerequisite for attendance. The school students and teachers that were invited to this event were all selected from the database of the University of Manchester's widening participation programme, which is designed to identify and attract the most talented students to Manchester, regardless of their educational background. The schools and teachers were provided with no guidance in terms of which of their students to target for this event. 
In 2014, 609 students provided feedback onthe NSEW Science Extravaganza at the University of Manchester. The following responses correspond to the question numbers shown in Figure 1 (in this analysis 'agreed' means that the students either 'strongly agreed' or 'agreed; with the statement):

1. $96 \%$ of students agreed that they found out something new about science

2. $82 \%$ of students agreed that the event taught them more about the different science and engineering courses you can study at university

3. $46 \%$ of students agreed that they were more likely to pursue a career in science as a result of the event

4. $78 \%$ of students agreed that at the event they had a chance to speak to a student/researcher about their work

5. $97 \%$ of students agreed that the science fair was interesting

6. $87 \%$ of students agreed that the workshop was enjoyable

7. $75 \%$ of students agreed that the lecture was interesting

8. $68 \%$ of students agreed that their perceptions of scientists changed as a result of the event

As can be seen from appendix 1, there were additional questions that were asked to students to further probe their knowledge and experience of universities, but these questions were omitted from this particular analysis.

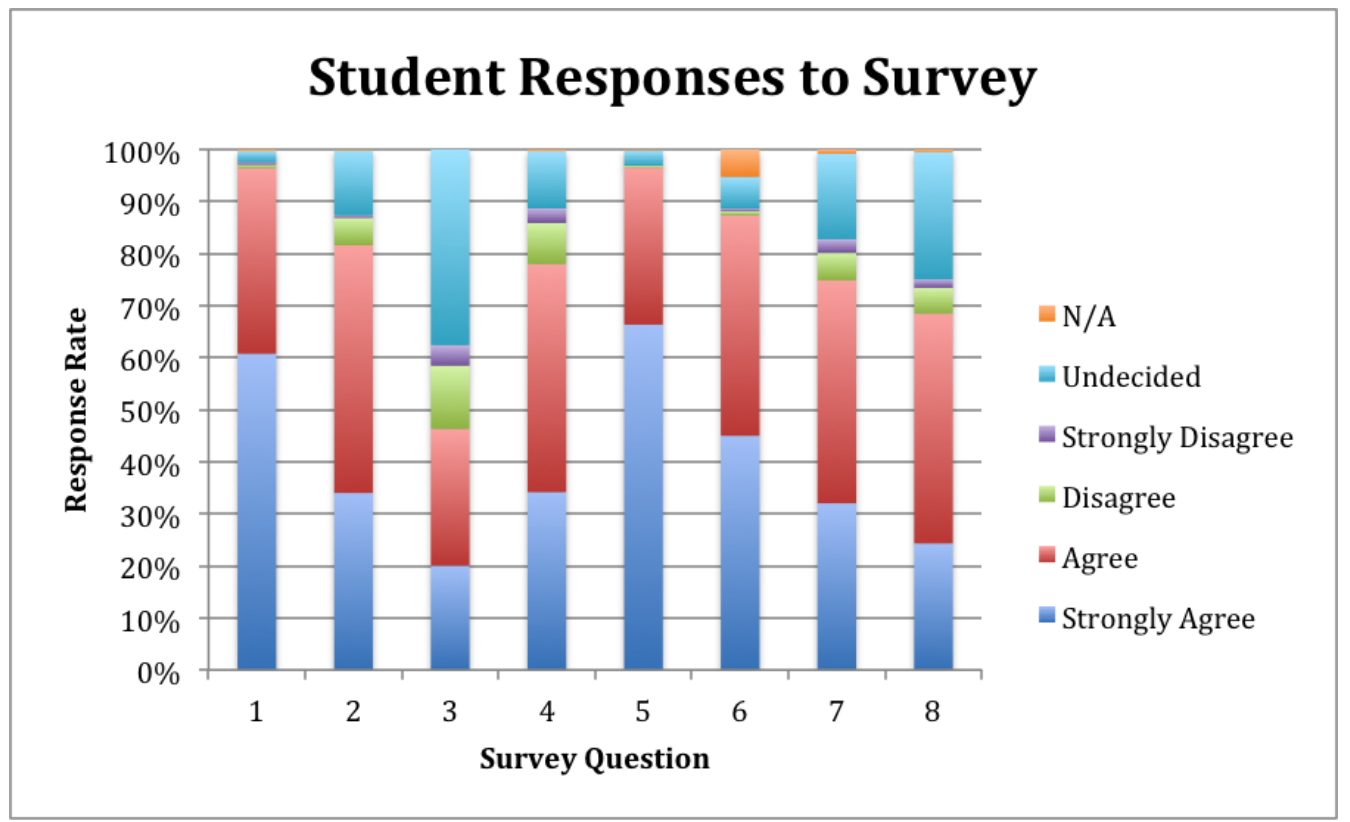

Figure 1. Stacked columns showing how students responded to their survey ( $n=609)$. The key to the Survey Question is given in the Methods section. 
Concerning the 61 teachers who provided feedback, the following responses correspond to the question numbers shown in Figure 2:

1. $93 \%$ of teachers thought that the event was a valuable experience for most or all of their students

2. $74 \%$ of teachers thought that most or all of their students had the opportunity to find out more about the courses and careers related to science and engineering

3. $92 \%$ of teachers thought for most or all of their students, the event will have increased their interest in studying science

4. $79 \%$ thought that the personal and academic aspirations of most or all of their students were raised

The survey also found that:

- $77 \%$ of teachers rated the science fair as excellent, $23 \%$ rated it as good

- $54 \%$ of teachers rated their workshop as excellent, $31 \%$ as good

- $59 \%$ of teachers rated the lecture as excellent, $30 \%$ as good

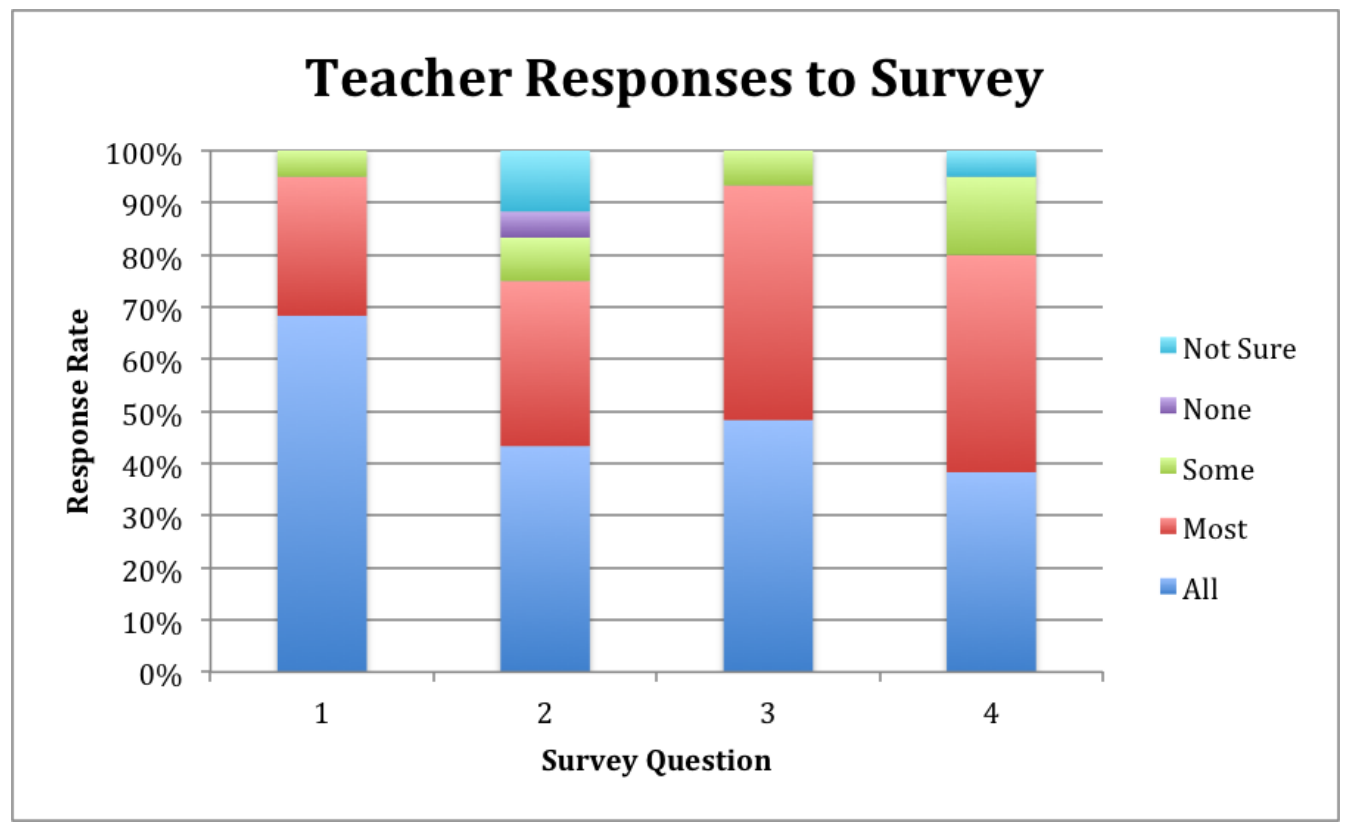

Figure 2. Stacked columns showing how teachers responded to their survey $(n=61)$. The key to the Survey Question is given in the Methods section.

Some of the questions that were asked to the students and the teachers also allowed for them to give more detailed, written answers. From these responses word clouds were created, in which an image was composed of the words used, for which the size of each word indicates its frequency. These word clouds are shown in Figure 3-5, all of which were produced using the web-based application Wordle (www.wordle.net). In the generation of these word clouds all of the words were capitalised, so as to avoid repetition. 
In their questionnaire, the students were asked to expand on how the event had changed what they thought about scientists, the results of which can be seen in Figure 3; listed below is a selection of the student's responses:

- Yes because they're not just people who look through a microscope

- Yes, because I've learnt more about the different careers

- Yes, because it's given me the opportunity to see what different scientists do and their research, not the cliché image of scientist you'll think they'll be

- Yes, I used to think they are boring now they are actually ok

- Yes because anybody can be a scientist

- No! It has just reiterated my longstanding opinion in that scientists are critical, important members of society whilst being hard working and innovative within their interesting careers.

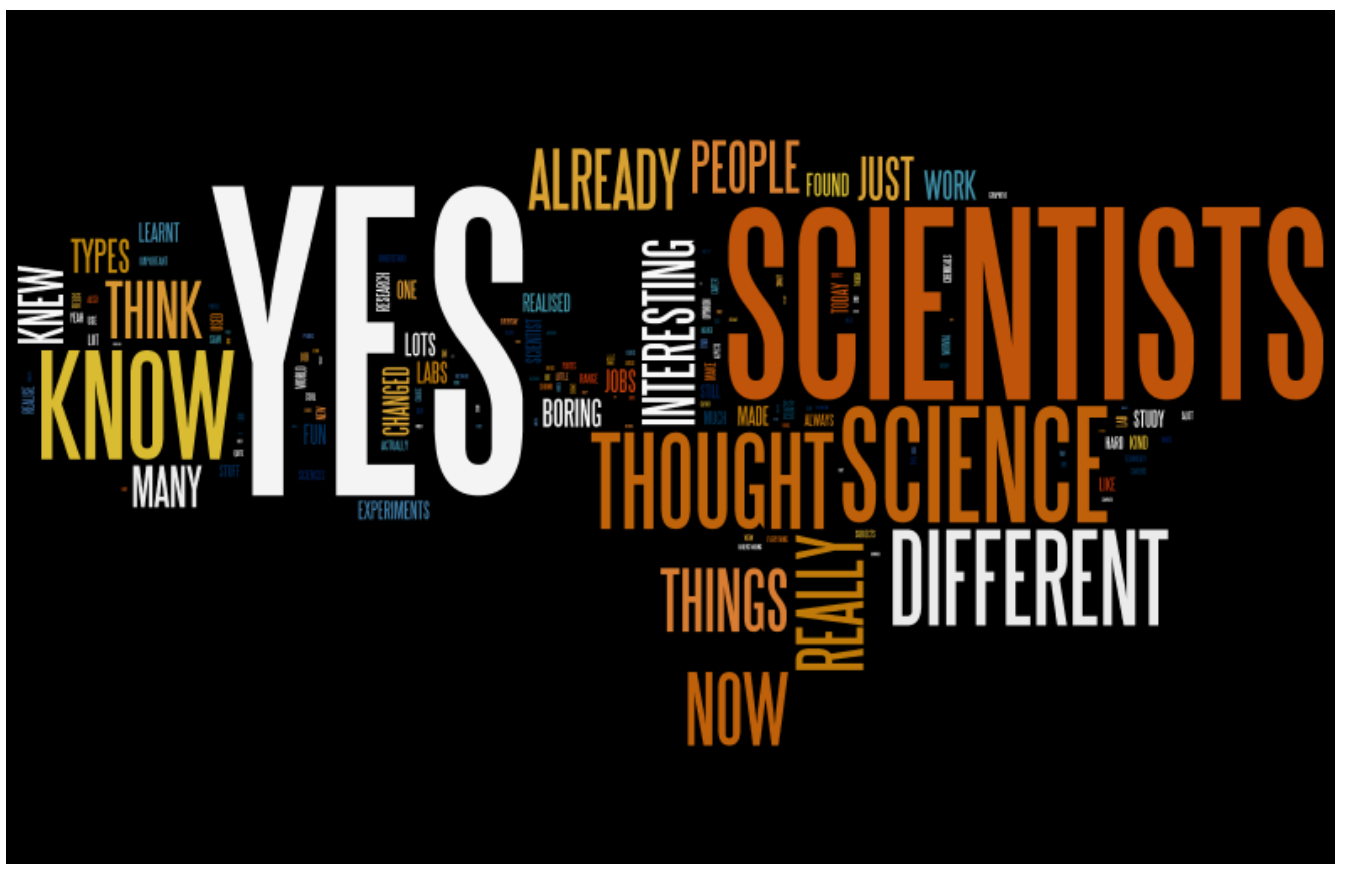

Figure 3. Word cloud of student's responses to the question: "Has today changed what you think about who scientists are; how?"

The teachers were asked, in their questionnaire, how they intended to take this experience forward with their students back in school, the results of which can be seen in Figure 4; listed below is a selection of the teacher's responses:

- Some of the demonstrations fit into our specification perfectly and could be incorporated into the lessons

- Develop and integrate a number of learning methods shown today

- Use some of the experiments from the Science Fair to enhance lessons and Science Club

- Feedback session and some assembly time

- Look for other events to reinforce what they have seen

- Asking pupils to deliver some sessions to other pupils when we return to school 


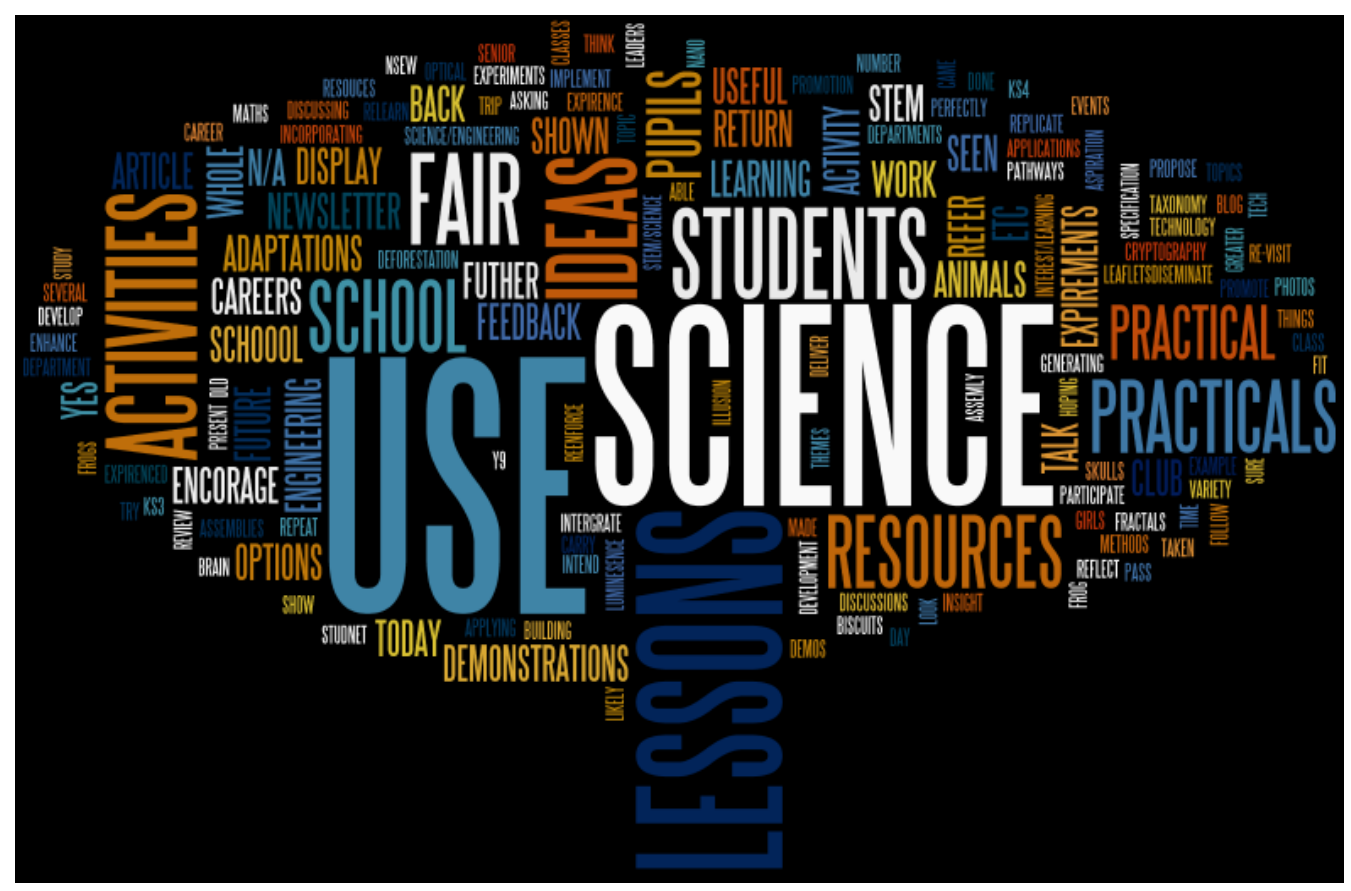

Figure 4. Word cloud of teacher's responses to the question: "How do you intend to take this experience forward with your students back in school?"

The teachers were also asked which part of the day they thought that their students found the most useful and enjoyable, the results of which can be seen in Figure 5; listed below is a selection of the teacher's responses:

- They learnt a lot during the workshop and were very attentive in the lecture

- The Science Fair gave them a broad understanding and a hands on opportunity

- Science Fair: linked some challenging concepts to their uses in everyday life, students found that interesting

- The talk was mesmerising, superbly delivered

- Workshop. Very well presented. Challenging and engaging

When asked about how the day as a whole could be improved, the majority of the teachers' suggestions were very practical, and were related to directions, walking between sites, shorter breaks for the students, and the provision of tea and coffee for the teachers.

The positive response to how the event changed the student's perceptions (as evidenced by the prominent 'YES' in Figure 3) is likewise reflected in the quantitative data for this study, with $68 \%$ of students agreeing that their perceptions of scientists changed as a result of the event. This percentage is probably higher, as some students quantitatively recorded that they disagreed with the statement, but then went on to qualitatively state that their perceptions had indeed changed. It is also worth noting that for many of the students that disagreed with this statement ( $7 \%$ either 'disagreed' or 'strongly disagreed'), their viewpoints remained unchanged but positive (see e.g. last testimonial listed above). Listed 


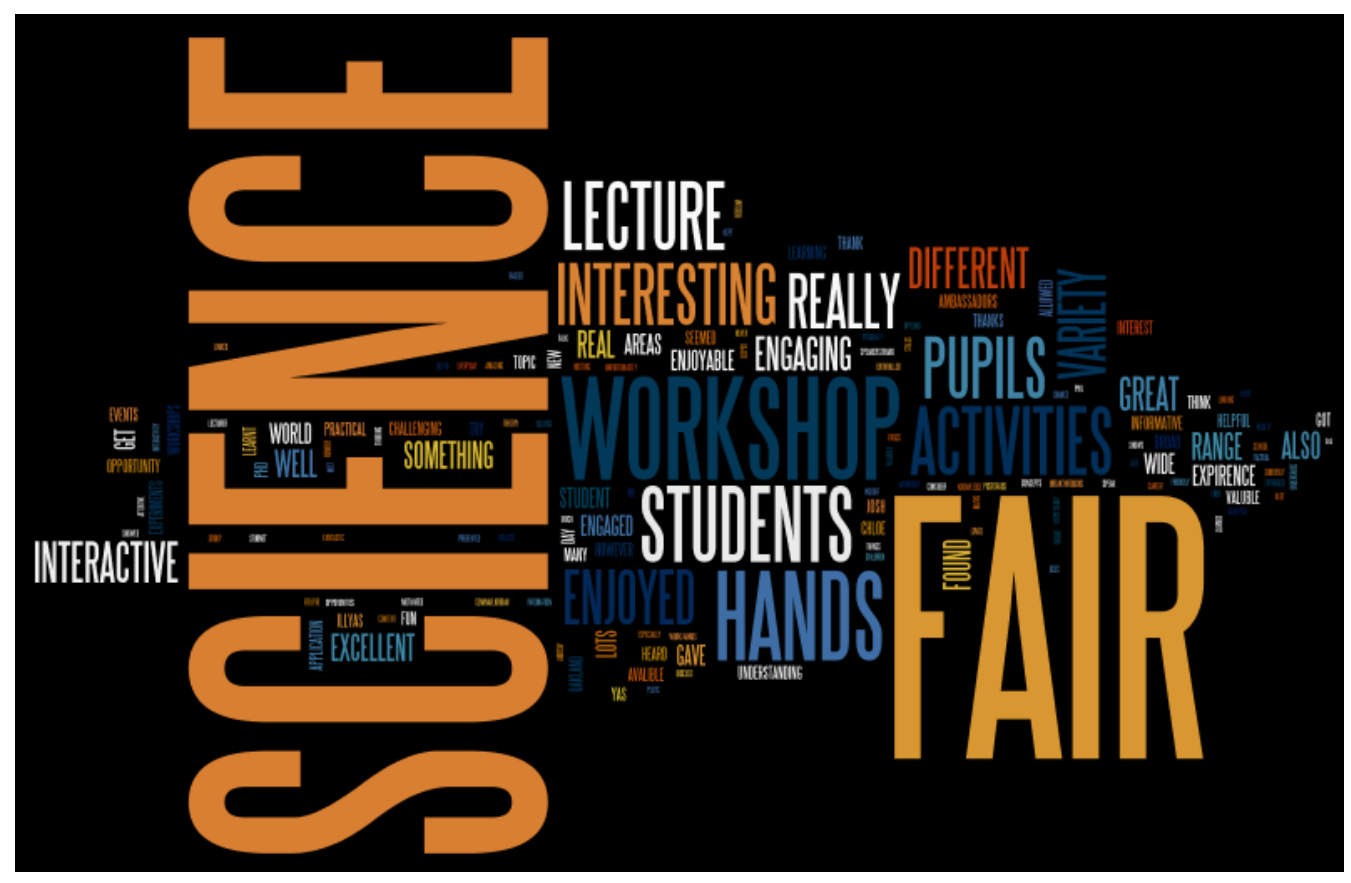

Figure 5. Word cloud of teacher's responses to the question: "Which part of today's event do you think your students found most useful and enjoyable; why?"

below are all six of the negative responses regarding how the event had changed what the students thought about scientists:

- I still think its boring but quite interesting

- Not really, just reinforced my previous assumptions (the student does not state what these assumptions are, whether positive or negative)

- No they're still people, nothing special

- Not really because I am more arty than science, so I haven't thought about it much

- I do not like science

- No because I didn't talk to many interesting scientists

The first two responses make it unclear how the student feels about the event, whilst the third, fourth, and fifth responses are more apathetic than specifically negative towards the event. Arguably then, it is only the final response that reflects negatively on the event in terms of changing perceptions of scientists.

Given the positive responses to how the event had changed their perceptions of scientists (Figure 1 and 3), it would appear counterintuitive that only $46 \%$ of the students agreed with the statement that they would be more likely to pursue a career in science as a result of the event. However, given that only $16 \%$ of the students disagreed with that statement, and that $38 \%$ were undecided, this is also perhaps reflective of the fact that many students in this age range are still indecisive about their future career prospects, with most Key Stage 3 students more likely to be focussed on post-16 choices [see e.g. Hemsley-Brown and Foskett, 1999]. Research has shown that STEM graduates remain stratified by social origin and ability, and that this sorting takes place during compulsory schooling, in the same 
way as it does for other high status subjects [Smith and Gorard, 2011]. It is therefore important that students are made aware of potential career choices as early as at Key Stage 3 (Years 7-9), and Key Stage 4 (Years 10-11, i.e. GCSE), when school students still have the opportunity to be selective in their choice of future study (in the UK, students are expected to make some choices regarding their subjects after Key Stage 3, for which science and maths are a compulsory subject; further specialism comes after Key Stage 4, when students determine the A-levels, for which science, maths, and indeed schooling is no longer compulsory)

Despite this muted response regarding the pursuit of a scientific career, the majority of the students agreed that the event had taught them more about the different science and engineering courses at university, and that they also had the chance to speak to a student/researcher about their work. Given that the vast majority of students also reported that the event either positively changed or reinforced their perceptions of scientists, this would suggest that the researchers did a very good job in enthusing students about science and the possibility of studying science at a university, but that they did not make clear the explicit link between studying science and pursuing a scientific career.

Another way in which the event could have succeeded in enthusing students about scientific careers, albeit indirectly, would be for the teachers to use elements of the activities, experiences, and conversations with researchers to address the issue of scientific careers back in the school classroom. Whilst the majority of the teachers did indeed indicate that they planned on using elements of the day's events to reflect and share back at their own schools, the survey suggested that this would mainly be in terms of experiments and demonstrations. The prominence of this approach is reflected by the prevalence of words such as 'USE', 'LESSON(S)' and 'PRACTICALS' in Figure 4; in fact there were only three responses that made explicit reference to careers, in terms of what would be practiced back at school:

- Think about careers options

- Encourage students with their careers and future pathways

- Use it to promote science/engineering interest and career options

In addition, there were the following related comments: "promotion for science A levels", and "encourage pupils to study science." This represents a total of five teachers out of $61(\sim 8 \%)$ that planned on using the experiences of the Science Extravaganza event to promote the further study of science subjects, with an emphasis instead being placed on what could be used to help enhance the teaching and understanding of the science curricula. However, it is important to consider the pressures that are exerted on teachers in terms of what must be covered in the classroom regarding the National Curriculum. As such, teachers providing detailed careers advice to students may not be practical due to restraints on the teachers in terms of both time and resources. Whilst many of the activities that are demonstrated at the science fair can be linked back to aspects of the taught curriculum, it would be necessary for any additional resources relating to careers to also have explicit links to the National Curriculum. For example, packs could be created which detailed the job specifications of a particular scientist, and how they used the science that is taught at Key Stage 3 and 4 in some of their daily tasks. This 
would have the added bonus of making the science that is taught in school feel more relevant to the children in terms of science-based careers.

As can be seen from Figure 5, the science fair was well received by the teachers, although the lecture and workshop were also praised for their effectiveness. However, from all of the surveyed responses, only two of the teachers made reference to the opportunity for students to speak to researchers, and the potential implications that this could have regarding career progression:

- The science fair was excellent! A hugely valuable experience for our students to meet and discuss science with grad students and academics

- Pupils had the opportunity to speak to undergrads and postgrads about their career path and how they can use science. Would be valuable to come into schools and do this

These results appear to contradict the qualitative data shown in Figure 2, in which the majority of the surveyed teachers agreed that their students had the opportunity to find out more about the courses and careers related to science and engineering. This would suggest that whilst the teachers acknowledged that their students did have the chance to speak to researchers, this was not seen as being one of the major benefits in attending the event.

Overall, the results of the student survey would seem to indicate that the science fair educated and enthused the school students about science (almost all of them reported that they learnt something new), without educating and enthusing them about scientific careers. This is in agreement with the findings of Kitts [2009], who note that whilst attempts to increase the numbers of students participating in science have been effective in changing student attitudes about science, they have been less successful in increasing the desire among students to become scientists [Kitts, 2009]. This is further substantiated by the results from the teacher survey, which indicate that this event did not explicitly enthuse them to discuss the role and potential of scientific careers back in the classroom.

In terms of enthusing young people about science careers, it seems clear that a new approach is needed to increase student participation, and that whilst large one-off events such as the Science Extravaganza evidently enthuse young people about science subjects, there needs to be a greater emphasis placed on both the teachers and the researchers to encourage the transition into an enthusiasm for finding out more about scientific careers. As noted by Massi et al. [2012], there is the potential to follow up on events such as this, to prepare students for and retain students in science pathways.

There is also the issue to consider that even if the researchers had been more successful in enthusing the school students about pursuing a scientific career, the majority of them would be doing so from the frame of reference of becoming an academic or a researcher at a university. In the UK, however, according to the Higher Education Statistics Agency (HESA: https:/ / www.hesa.ac.uk/stats-dlhe), only $20 \%$ of science graduate students went on to do further study after their first degree. Similarly, a report by the Royal Society [2010] found that less than half of UK students completing a science PhD stayed in research. There are clearly many 
science-related careers outside of higher education that can be pursued, which needs to be made clear if large science events like this are to be successful in enthusing students about science careers in general. Indeed, there is the possibility that such events may actually have the reverse effect, if school students are led to believe that becoming an academic is the only scientific career available.

\section{Conclusions}

Based on the results of this study, the following are four recommendations for future large, one-off science events in an informal setting, which should help to further enthuse school students about scientific careers:

1. Make sure that the researchers are well briefed, and that they know that as well as explaining their research, they should take the opportunity to talk to the school students about their own career paths, and why they chose them.

2. Prepare some material relating to different scientific careers, which the teachers can take away with them and use back in the classrooms. Crucially, these should be prepared in such a way as to be of benefit to the teacher as well, rather than as an additional, extracurricular demand.

3. Consider inviting a speaker from a scientific, but non-academic background to talk about their own career path, and how they use science in their job.

4. If running a science fair with a number of stalls, think about inviting some scientific companies or recruitment agencies to attend.

This article began by discussing how informal learning could be used to enthuse school students about science-related careers. However, Dierking et al. [2003] define an informal science education to be voluntary, whereas the school students that were involved in the Science Extravaganza did so as part of their taught curriculum. That being said, no guidance was given to the students in terms of what activities they could or could not attend. The event discussed in this article is therefore probably better identified as science learning taking part in a non-formal environment, rather than as an entirely informal experience, such as a student might get by attending a science museum or public lecture of his or her own volition.

Since 2013, some local Manchester primary schools have also been invited to attend the Science Extravaganza. Whilst these students make up a small percentage of the cohort $(\sim 9 \%)$, and are not included in this study, the following is testimony from a teacher commenting on the 2014 event:

"I'm sure that it has sown the seeds of interest for the future and inspired some of them to look into this field when they are older."

It is the conclusion of this study that such sowing of seeds needs to be made more explicit for future events, and that this can be done by actively encouraging researchers to talk to students about their own career paths, and by providing relevant resources to teachers so that the learning experience can continue in a more formal setting back in the school classroom.

Acknowledgments We gratefully acknowledge the participation of all of the people who took the time to fill in the survey used in this study, and also all of the researchers, staff, and students who made it possible. 
Appendix 1:

pupil

questionnaire
National Science and Engineering Week 2014

Pupil Evaluation Form

Name of your School:

Date Attended:

Your home postcode:

This is just for our evaluation purposes and we won't contact you!

CORE QUESTIONS: Please read the statements below and put a cross in the box which is closest to your answer. We would like to ask you what you now think about university because of your visit today:

\begin{tabular}{|l|l|l|l|l|l|}
\hline After today's event... & $\begin{array}{l}\text { Strongly } \\
\text { Agree }\end{array}$ & Agree & Undecided & Disagree & $\begin{array}{l}\text { Strongly } \\
\text { Disagree }\end{array}$ \\
\hline $\begin{array}{l}\text { 1. I know more about the benefits of go- } \\
\text { ing to university. }\end{array}$ & & & & & \\
\hline $\begin{array}{l}\text { 2. I now have a better understanding of } \\
\text { how University is different from school. }\end{array}$ & & & & & \\
\hline $\begin{array}{l}\text { 3. I now have a better idea of what I } \\
\text { would need to do if I wanted to go to uni- } \\
\text { versity. }\end{array}$ & & & & & \\
\hline $\begin{array}{l}\text { 4. I enjoyed today's visit. } \\
\text { 5a. Before today's visit I had already } \\
\text { thought about going to university. }\end{array}$ & & & & & \\
\hline $\begin{array}{l}\text { 5b. Today's visit has made me more } \\
\text { likely to consider going to university. }\end{array}$ & & & & & \\
\hline
\end{tabular}

\begin{tabular}{|l|l|l|l|l|l|}
\hline After today's event... & $\begin{array}{l}\text { Strongly } \\
\text { Agree }\end{array}$ & Agree & Undecided & Disagree & $\begin{array}{l}\text { Strongly } \\
\text { Disagree }\end{array}$ \\
\hline $\begin{array}{l}\text { 1. I found out something about Science } \\
\text { that I didn't know before }\end{array}$ & & & & & \\
\hline $\begin{array}{l}\text { 2. I know more about the different Sci- } \\
\text { ence and Engineering courses you can } \\
\text { study at university. }\end{array}$ & & & & & \\
\hline $\begin{array}{l}\text { 3. As a result of this event - I am more } \\
\text { likely to pursue a career in science }\end{array}$ & & & & & \\
\hline $\begin{array}{l}\text { 4. At this event, I had a chance to speak } \\
\text { to a student/researcher about their work }\end{array}$ & & & & & \\
\hline $\begin{array}{l}\text { 5. I thought the Science Fair was interest- } \\
\text { ing. }\end{array}$ & & & & & \\
\hline $\begin{array}{l}\text { 6. I found the workshop session enjoy- } \\
\text { able. }\end{array}$ & & & & & \\
\hline $\begin{array}{l}\text { 7. The afternoon lecture was interesting. } \\
\text { 8. My perceptions of scientists has } \\
\text { changed after attending this event. }\end{array}$ & & & & & \\
\hline
\end{tabular}


9. Has today changed what you thin $\mathrm{k}$ about who scientists are? How?

10. The part of the day I enjoyed the most was:

11. One thing I will remember from the event today is:

12. One thing which could have made today better is: 
Appendix 2: teacher questionnaire

March 2014 National Science and Engineering Week TEACHER EVALUATION FORM

Name

School

Date attended

So that we are better able to measure the impact of our activities, please can you answer the following questions.

\begin{tabular}{|l|l|l|l|l|l|}
\hline & $\begin{array}{l}\text { None of } \\
\text { them }\end{array}$ & $\begin{array}{l}\text { Some of } \\
\text { them }\end{array}$ & $\begin{array}{l}\text { Not } \\
\text { Sure }\end{array}$ & $\begin{array}{l}\text { Most of } \\
\text { them }\end{array}$ & $\begin{array}{l}\text { All of } \\
\text { them }\end{array}$ \\
\hline $\begin{array}{l}\text { The event was a valuable experience } \\
\text { for my students }\end{array}$ & & & & & \\
\hline $\begin{array}{l}\text { They had the opportunity to find out } \\
\text { more about the courses and careers } \\
\text { related to science and engineering. }\end{array}$ & & & & & \\
\hline $\begin{array}{l}\text { The event will have increased their } \\
\text { interest in studying science. }\end{array}$ & & & & & \\
\hline $\begin{array}{l}\text { The students' personal and academic } \\
\text { aspirations were raised }\end{array}$ & & & & & \\
\hline
\end{tabular}

Please rate the following elements of the event.

\begin{tabular}{|l|l|l|l|l|}
\hline & Excellent & Good & Satisfactory & Poor \\
\hline Science Fair & & & & \\
\hline Workshop & & & & \\
\hline Lecture & & & & \\
\hline
\end{tabular}

Which part of today's event do you think your students found most useful and enjoyable? Why?

How do you intend to take this experience forward with your students back in school?

Are there any aspects of the event that could be improved? And how? 
Baram-Tsabari, A. and Yarden, A. (2005). 'Characterizing children's spontaneous interests in science and technology'. International Journal of Science Education 27 (7), pp. 803-826.

Buldu, M. (2006). 'Young children's perceptionsof scientists: a preliminary study'. Educational Research 48 (1), pp. 121-132.

Bultitude, K., McDonald, D. and Custead, S. (2011). 'The Rise and Rise of Science Festivals: an international review of organised events to celebrate science'. International Journal of Science Education, Part B 1 (2), pp. 165-188.

Clemence, M., Gilby, N., Shah, J., Swiecicka, J., Warren, D., Smith, P., Johnson, J., Nissen, S., Hoolahan, F. and d'Souza, J. (2013). Wellcome Trust Monitor: Wave 2 Tracking public views on science, biomedical reserach and science education. Wellcome Trust. URL: http://www.wellcome.ac.uk/stellent/groups/ corporatesite/@msh_grants/documents/web_document/wtp052603.doc.

Dierking, L. D., Falk, J. H., Rennie, L., Anderson, D. and Ellenbogen, K. (2003). 'Policy statement of the "Informal Science Education" Ad Hoc committe'. Journal of Research in Science Teaching 40 (2), pp. 108-111.

Gjersoe, N. L. and Hood, B. (2013). 'Changing children's understanding of the brain: a longitudinal study of the royal institution christmas lectures as a measure of public engagement'. PLoS ONE 8 (11), pp. 512-556. DOI: 10.1177/0162243903259197.

Gregory, J. and Miller, S. (2000). Science in public. New York, U.S.A.: Basic Books.

Hemsley-Brown, J. and Foskett, N. H. (1999). 'Career desirability: young people's perceptions of nursing as a career'. Journal of Advanced Nursing 29 (6), pp. 1342-1350.

Jensen, E. and Buckley, N. (2014). 'Why people attend science festivals: interests, motivations and self-reported benefits of public engagement with research'. Public Understanding of Science 23 (5), pp. 557-573.

Kitts, K. (2009). 'The paradox of middle and high school students' attitudes towards science versus their attitudes about science as a career'. Journal of Geoscience Education 57 (3), pp. 159-164.

Martín-Sempere, M. J., Garzón-García, B. and Rey-Rocha, J. (2008). 'Scientists' motivation to communicate science and technology to the public: surveying participants at the Madrid Science Fair'. Public Understanding of Science 17 (3), pp. 349-367. DOI: 10.1177/0963662506067660.

Massi, L., Reilly, C. H., Johnson, D. and Castner, L. (2012). 'Expanding Your Horizons: the impact of a one-day STEM conference on middle school girls' and parents' attitude toward STEM careers'. In: ASEE Annual Conference and Exposition. Conference Proceedings.

Muller, C. L., Roberts, S., Wilson, R. C., Remedios, J. J., Illingworth, S., Graves, R., Trent, T., Henderson, J., Wilkinson, J., Wilkinson, M. and Desai, A. (2013). 'The Blue Marble: a model for primary school STEM outreach'. Physics Education 48 (2), pp. 176-183. DOI: 10.1088/0031-9120/48/2/176.

Ramey-Gassert, L. (1997). 'Learning Science beyond the Classroom'. Elementary School Journal 97 (4), pp. 433-450.

Redfern, J., Burdass, D. and Verran, J. (2013). 'Transforming a school learning exercise into a public engagement event: the Good, the Bad and the Algae'. Journal of Biological Education 47 (4), pp. 246-252.

Royal Society (2010). The Scientific Century: Securing Our Future Prosperity. London, U.K.: Royal Society. 
Sadler, P. M., Sonnert, G., Hazari, Z. and Tai, R. (2012). 'Stability and volatility of STEM career interest in high school: a gender study'. Science Education 96 (3), pp. 411-427. DOI: $10.1002 /$ sce. 21007.

Salmi, H. (2003). 'Science centres as learning laboratories: Experiences of Heureka, the Finnish Science Centre'. International Journal of Technology Management 25 (5), pp. $460-476$.

Smith, E. and Gorard, S. (2011). 'Is there a shortage of scientists? A re-analysis of supply for the UK'. British Journal of Educational Studies 59 (2), pp. 159-177.

Tamir, P. (1991). 'Factors Associated with the Relationship between Formal, Informal, and Nonformal Science Learning'. The Journal of Environmental Education 22 (2), pp. 34-42.

Author

Sam Illingworth is a lecturer in science communication in the School of Research, Enterprise \& Innovation, at Manchester Metropolitan University, UK. His research includes investigating the relationship between science \& poetry, and how theatrical technique can be used to improve effective communication skills. E-mail: s.illingworth@mmu.ac.uk.

Emma Lewis is an undergraduate recruitment and widening participation officer at the University of Manchester, UK. Her work involves increasing the awareness of, and aspiration to study STEM courses at university level.

E-mail: emma.lewis@manchester.ac.uk.

Carl Percival is a professor of atmospheric chemistry at the University of Manchester, UK. His work involves studying the sources and fate of pollution in the atmosphere, which involve simulating the atmosphere in the laboratory and investigate key chemical process. E-mail: carl.percival@manchester.ac.uk.

How to cite

This article is licensed under the terms of the Creative Commons Attribution - NonCommercial NoDerivativeWorks 4.0 License.

ISSN 1824 - 2049. Published by SISSA Medialab. http:/ /jcom.sissa.it/. 